\title{
Shaky Grounds: The Case Against the Case Against Antidiscrimination Laws
}

Peter Siegelman

University of Connecticut School of Law

Follow this and additional works at: https://opencommons.uconn.edu/law_papers

Part of the Civil Rights and Discrimination Commons

\section{Recommended Citation}

Siegelman, Peter, "Shaky Grounds: The Case Against the Case Against Antidiscrimination Laws" (1994).

Faculty Articles and Papers. 460.

https://opencommons.uconn.edu/law_papers/460 


\section{Shaky Grounds: \\ The Case against the Case against Antidiscrimination Laws}

Peter Siegelman

Ruchard Epstein, Forbidden Grounds: The Case against Employment Discrimination Laws. Cambridge, Mass.: Harvard University Press, 1991. Pp. $\mathrm{xvi}+530 . \$ 39.95$.

Many readers of Law and Social Inquiry will probably feel that all they need to know about Forbidden Grounds is that in it, prominent libertarian law professor Richard Epstein argues that there should not be any. The central thesis of this book is that (virtually all) federal and state laws regulating discrimination in employment are a bad thing - both for society at large and for those the laws are designed to protect-and should be repealed immediately. In other words, Epstein believes that the state should not forbid firms (and, he would add, workers) from making employment decisions on any grounds whatever, including race, sex, age, or religion.

Epstein himself acknowledges, in a rare moment of understatement, that this view is "well outside the mainstream of American political thought" (at 6). In fact, he seems to take considerable pride in puncturing the orthodox views of discrimination espoused by courts, politicians, and academic commentators. But that by itself is no reason to ignore the book. After all, many of yesterday's outré theories are now widely accepted or in-

Peter Siegelman is a Research Fellow, American Bar Foundation. Siegelman writes: "Virtually everything I know about employment discrimination I learned from John Donohue and James Heckman. Although I cite their work frequently in this review, these references cannot document the important influences both have had on me over the course of many, many conversations. I am also grateful to Ian Ayres, Eugene Bardach, and Sean Redding for helpful discussions, and to Philip Siegelman for his extensive comments, both substantive and editorial. Some of this review was written while I was visiting in the Black Studies Department at Amherst College, and participants in the Department's colloquium also made helpful suggestions." 
fluential. There is a place for outrageousness if it provokes serious reflection and debate or inspires further work designed to fill gaps in existing knowledge. Epstein had the opportunity to write such a book, but I'm afraid this isn't it. That's a shame, because beneath the overconfident assertions and the rhetoric, I think there are some things worth taking seriously in Epstein's book, and I can almost guarantee that most readers of this journal will never consider them.

As an economist, I have a second reason for coming away from Forbidden Grounds with a sense of foreboding. Whether or not it is actually read, I have a sinking feeling that the book is going to be treated as yet another piece of evidence confirming the depravity of economists. Who but an economist, after all, could argue that competitive markets are better than governments at eliminating discrimination? Who else could claim that discrimination against African Americans before the passage of the 1964 Civil Rights Act was only maintained by government fiat, and would have vanished if governments' regulatory powers had been appropriately limited by the courts? Who else could suggest that the costs of antidiscrimination laws outweigh their benefits? Who else could claim that in making policy decisions, the preferences of bigots deserve equal weight with those who are being discriminated against?

Epstein has used enough of the language of economics to lead the uninitiated into believing that Forbidden Grounds is what you get when you turn economic thinking on the problem of employment discrimination. But I think it is important to stress to readers of LSI that although some of its insights-including the most important one that there are costs to antidiscrimination policies-do derive from economic thinking, Forbidden Grounds is not a work of economics. (Nor, I hasten to add, does it claim to be: I simply want to make this clear to potential readers of the book.)

Let me briefly list why not. Stylistically, Forbidden Grounds is too bold, and its prose is too well crafted and accessible, to have come from a "dismal scientist." Nor does Epstein use any of the social scientist's standard analyti$\mathrm{cal} /$ rhetorical tools: ${ }^{1}$ the reader who expects regression analysis, mathematical models, equations, graphs, or even tables will be surprised, if not pleased, by their absence. But it is the intellectual framework in which the book is written that provides the most important evidence of its provenance. Epstein does briefly discuss the two leading economic theories of discrimination; but he ignores almost all the empirical economic literature on labor markets and discrimination-not to mention the literature of any other so-

1. There is an obvious connection between this sentence and the previous one. As S. J. Perelman put it, "There's nothing like a good, painstaking survey full of decimal points and guarded generalizations to put a glaze like a Sung vase on your eyeball" (Keep It Crisp 173 (New York: Random House, 1946)). Epstein may cause steam to come out of your ears, but your eyes will certainly not glaze over when reading him-there are virtually no decimal points in Forbidden Grounds, and the generalizations are anything but guarded. 
cial sciences. A comparison of Forbidden Grounds with Glen Cain's impressive survey chapter in the Handbook of Labor Economics ${ }^{2}$ immediately reveals how far Epstein's views are from the mainstream of the economics profession.

To provide some rough sense of Epstein's intellectual influences, I classified the citations on a random sample of 50 pages (one-tenth of the book). Table 1 supports my contention that Epstein is not an economist. Only 11\% of his citations are to works by $\mathrm{Ph}$.D. economists; and this quantitative measure actually makes Epstein look more like an economist than he really is. For example, no economist writing on discrimination would give equal weight to Jennifer Roback (a libertarian economic historian) and Kenneth Arrow (probably the leading economic theorist of the postwar generation and one of the pioneers of the economics of discrimination), yet each receives two mentions in Epstein's index. Missing entirely from the book are Orley Ashenfelter, Alan Blinder, Francine Blau and Marianne Ferber, George Borjas, Glen Cain, Barry Chiswick, Lawrence Kahn, Jonathan Leonard, Ronald Oaxaca - to name only a few of those who have made important theoretical or empirical contributions to the study of discrimination.

\section{TABLE 1}

Citations in a 1-in-10 Random Sample (50 Pages) from Forbidden Grounds

\begin{tabular}{lrc}
\hline Source & Count & $\%^{\mathrm{a}}$ \\
\hline Cases, laws, legislative histories & 67 & 61.4 \\
Articles in law reviews ${ }^{\mathrm{b}}$ & 16 & 14.7 \\
Books & 9 & 8.2 \\
Of books, by Ph.D. economists & $(1)$ & $(0.9)$ \\
Joumal of Law and Economics or & 6 & 5.5 \\
$\quad$ Joumal of Legal Studies & 6 & 5.5 \\
Work by Epstein & 5 & 4.6 \\
Articles in economics journals & 0 & 0.0 \\
Articles in other social science journals & 1 & 0.9 \\
Newspapers & 109 & 100.0 \\
Total citations & $(12)$ & $(11.0)$ \\
Of total, to Ph.D. economists & &
\end{tabular}

Total does not sum to $100 \%$ because of rounding.

b None by Ph.D. economists.

c Includes all cites to Epstein's work, regardless of where it appeared.

What Epstein has produced, in sum, is not a work of social science at all but an extended lawyer's brief against employment discrimination laws

2. Glen Cain, "The Economic Analysis of Labor Market Discrimination: A Survey," in O. Ashenfelter \& R. Layard, eds., 1 Handbook of Labor Economics (Amsterdam: Elsevier Scientific, 1986) ("Cain, 'Economic Analysis'"). 
that uses a simple, sectarian version of economic theory, where helpful, to make an argument about the folly and immorality of trying to curtail discrimination through law. While a certain kind of economic logic informs some of Epstein's argument, the economics is really peripheral to a much more fundamental philosophical premise-that government is bad and that the best society is one in which freedom of contract is maximized by drastically limiting the scope of government. This is a libertarian vision. And while economists do have much more faith in markets (and less in government) than most other social scientists, they have a lot less than libertarians do.

Even though I argue that Forbidden Grounds is not good economics, it may well be very good something else; and indeed, one has to admire Epstein for writing an overview of employment discrimination law that draws on philosophical, historical, jurisprudential, and economic arguments with great zeal and clarity. These same qualities, however-the book's enormous breadth and its sublimely confident tone-make it a difficult work to review. Ideally, the task should be handled by a tag team of reviewers, one from each of the disciplines Epstein draws on. I strongly suspect each would conclude the same thing about his or her own field that I do about Epstein's use of economics: Some of my discipline is recognizable in Epstein's book, but he's picked and chosen his facts and theories to fit his case and hasn't provided a representative sample of the discourse on which he's drawn.

After a summary of the book's main arguments, this review attempts to provide an alternative assessment of some of the philosophical, historical, legal, and economic issues Epstein raises. My main goal is to demonstrate that economics has something useful to contribute to the debate on these issues and that it is usually not what Epstein offers us.

\section{A BRIEF OVERVIEW}

Epstein's book is divided into six sections. In the first of these, "Analytical Foundations," he lays out his philosophical grounds for opposing government intervention in labor markets. (He also very briefly discusses some of the empirical evidence for the existence of discrimination, a topic I take up at greater length below.) Simply put, Epstein believes that maximizing individual freedom to make contracts will maximize social welfare and that any "restrictions" on such freedom will inevitably make some (and often all) of society worse off. (The exceptional case of labor market monopsony/monopoly does, in Epstein's view, justify limited government intervention.) Following Gary Becker, the originator of the economic analysis of discrimination, Epstein also stresses that competitive markets will by themselves 
provide a check on discriminatory behavior, although he seems to go further than Becker does in this respect. ${ }^{3}$

The second section of the book-"History"-gives Epstein's view of the development of employment law since 1890. The basic theme of this section-probably the most novel and provocative of the book-is that discrimination against blacks was produced and sustained not by the operation of competitive markets but through the mandates of state and local governments (especially in the South). ${ }^{4}$ If federal courts had not abdicated their responsibility to limit the "police power" of state and local governments, Epstein claims, Jim Crow legislation could have been struck down and covert governmental pressure to discriminate ${ }^{5}$ could have been drastically reduced. After a brief detour to attack the New Deal (minimum wages, collective bargaining), Epstein takes us to the 1964 Civil Rights Act, whose effects he both applauds and deplores. To the extent that Title VII forbids discrimination by governments, Epstein is a fan of the antidiscrimination statute. But in going beyond that-to mandate nondiscrimination by private actors-Epstein sees the law as encroaching on citizens' fundamental freedoms to choose the parties with whom they want to make contracts, without providing much, if anything, by way of benefits to those it is supposed to protect.

The third and fourth sections of the book take up the law of race and sex discrimination as they now stand and offer Epstein's critique. (I ignore sex discrimination to keep this review to a manageable length.) After another brief detour in chapter 8 to take a swipe at the "just cause" rule in employment contracts, ${ }^{6}$ Epstein examines the two major types of race dis-

3. Writing in the late 1960 s, Becker noted:

A few of the more extreme nineteenth-century advocates of a competitive marker economy believed that eventually its extension and development would eliminate most economic discrimination. . . . Unfortunately, this has not yet taken place; discrimination exists, and at times even flourishes, in competitive economies, the position of Negroes in the United States being a clear example.

"Discrimination" in International Encyclopedia of the Social Sciences 210 (1968). Had this not been written 25 years ago, it could be taken as a direct slap at Epstein.

4. Epstein scarcely mentions the North, where Jim Crow laws were insignificant. His analysis would seem to require that in the absence of such laws there should be virtually no discrimination. Yet in the two decades between the end of World War II and the passage of the 1964 Civil Rights Act, most Northem states felt discrimination against blacks by private employers was enough of a problem to warrant adoption of fair employment practice laws designed to prohibit it.

5. At several points, Epstein suggests that at least until the passage of Title VII and the Voting Rights Act, local governments used their regulatory or "police" powers-ranging from control over sewer hookups to zoning and building code enforcement-to reinforce (or substitute for) direct mandates of discrimination. These powers, Epstein asserts, constituted "the vehicle that allowed local governments to trample the ordinary rights of property and contract, which were as valuable to blacks as they were to whites" (at 115).

6. Chapter 8 of the book reads as if Epstein, a long-time defender of the "at will" contract in employment (giving the employer the right to terminate the employee for any reason, or no reason), just couldn't resist the chance to deploy his arguments yet again. For a fuller exposition, see Epstein, "In Defense of the Contract at Will," 51 U. Chi. L. Rev. 947 (1984). 
crimination claims: "disparate treatment" (explicit or intentional use of race or other prohibited classifications in making employment decisions) and "disparate impact" (employment practices that are neutral on their face but disproportionately hurt people in one of the classes protected by the law). Although he raises some objections (discussed below), Epstein is surprisingly mild in his critique of the disparate treatment doctrine. He reserves his greatest scorn for disparate impact, which he attacks as being inconsistent with congressional intent and as massively costly to employers.

After arguing that mandatory affirmative action constitutes discrimination against whites/males (and is inconsistent with the legislative history and philosophy of Title VII), Epstein in section 5 makes the case that firms should be allowed to practice affirmative action if they wish to do so. This is entirely in keeping with Epstein's overall view that decisions about whom to "employ and under what conditions should be left entirely to employers, who should be free to discriminate, in favor of white males or against them, as they see fit. The final section of the book discusses discrimination on the basis of age and handicapped status, which I will ignore because of space constraints.

\section{FIRST PRINCIPLES AND PHILOSOPHICAL PROBLEMS}

Epstein begins with a section called "Analytical Foundations," the goal of which is to undermine the theoretical or philosophical justifications for antidiscrimination law. Or, rather, it is more accurate to say that Epstein sets out to bolster the libertarian notion that government has no business intervening to "correct" preferences or tastes (such as for discrimination or pornography). Put simply, employment discrimination laws clearly make some people (bigots) worse off by forcing them to associate with persons they would prefer to avoid. In Epstein's libertarian world view, it is impossi-

The discussion has relatively little relevance to issues of race and sex discrimination. True, ruling out race and sex as legitimate grounds for dismissal was a first step in eroding the at will contract. But that point could be made in a single sentence, and certainly doesn't require an entire chapter.

Moreover, Epstein's analysis of the at will contract is flawed. For more perceptive treatments of these issues, the interested reader should consult Edward Lazear, "Job Security Provisions and Employment," 105 Q.J. Econ. 699 (1990); and David Levine, "Just Cause Employment Policies in the Presence of Worker Adverse Selection," 9 J. Lab. Econ. 294 (1990). One key argument in favor of the at will contract is that if both workers and employers would rather have a just cause rule, they are free to write it into the employment contract. However, Levine's model demonstrates that if workers know more about their own productivity than employers do, a worker who asks for just cause protection will signal to her employer that she believes she is likely to be fired. To avoid sending such a signal, workers may be forced to accept the at will rule when both workers and employers would prefer just cause contracts (with appropriate side payments). That is, even if workers would be willing to concede more in wages to get a just cause rule than employers would require to give up their power to fire at will, workers' desire to avoid signaling low productivity may prevent this beneficial agreement from being reached. 
ble to rank preferences, or at least to rule out certain preferences as morally inferior and unworthy of respect; thus, laws to help blacks, women, Jehovah's Witnesses, or anyone else, at the expense of those who would prefer not to hire them, are unjustifiable.

This section of the book raised two questions in my mind. First, how useful is an a priori theoretical approach that seeks to derive good laws only, or largely, from abstract first principles? To be sure, Epstein's comprehensive worldview gives him an important rhetorical advantage-he can offer us a few innocuous or appealing initial assumptions and then spin out a consistent argument from them that leads, seemingly inexorably, to the conclusion that, by gosh, we'd be better off without Title VII.

But why not some other set of first principles? Why not start from Marx or Rawls instead of Smith or Hobbes, as Epstein does?? Or why start from first principles at all? Take a question like, Should firms be required to validate any tests they use in screening potential employees? How would we recognize a good answer to this question? Would it consist of a seamless, consistent logical derivation from the few abstract principles to which we have all (?) agreed at the start? If so, then assessing Title VII or any other law is really an exercise in applied philosophy, and the crucial questions are, What first principles do you start from? and How rigorously do you derive your conclusions from your premises? Empirical evidence is really of secondary importance-useful for footnotes but not the meat of the argument.

My own view is that empirical evidence, and judgments based on it, are crucial, not as substitutes for basic judgments about justice and morality but as complements to them. The line from the philosopher/theorist's pristine hypothetical world to the messy reality of this one meanders through a lot of murky territory. Any attempt to derive an appropriate antidiscrimination law from philosophical first principles is unlikely to be very productive because the real problems with the law are not problems of first principles but problems of implementation, behavior, and so on that are fundamentally empirical and messy, and cannot be resolved either by pure logic or by appeals to abstract virtues such as freedom of contract. ${ }^{8}$ It's fine to think

7. And why Hobbes, who, after all, believed that we needed a strong state-a Leviathan-to prevent the war of all against all? Doesn't this seem like a rather strange starting point for a libertarian? I'm grateful to Richard McAdams for this point. His perceptive discussion of Epstein's misreading of Hobbes-especially given the latter's emphasis on honor and dignitary harms as causes of social turmoil that necessitate a strong state-appears in the San Diego Law Review symposium on Forbidden Grounds, 31 San Diego L. Rev. -, - (1994).

8. Sociologist Christopher Jencks makes the case for an empirical component in public policy judgments very well:

Some ideological differences are simply a matter of conflicting values. ... In cases of this kind, making the same value judgment in every situation, regardless of context, seems to make sense. But most ideological arguments depend on facts as well as values. ... When facts matter, applying the same principles to every situation leads to foolishness. ... We know that many people respond to economic incentives. All else equal, therefore, sensible people expect that raising AFDC benefits will encourage both out-of-wedlock births 
about what we might do in the state of nature or behind the veil of ignorance, but as public policy analyst Eugene Bardach has noted, ${ }^{9}$ the really tough issues arise once the veil has been lifted, which is when empirical social science can usefully be brought to bear on some of these questions.

This section of Forbidden Grounds also raises a second question, an old one in the history of political theory: What are the limits of state action in a modern welfare state, and how do we distinguish between those things we want governments to be able to do and those that we want to say are off limits? If the state can ignore the preferences of bigots by enforcing antidiscrimination laws, can it also ignore the preferences of pornographers, or Communists, or pro-choice advocates? $\mathrm{Or}$ is there some way of distinguishing legitimate government behavior from illegitimate?

Epstein offers a libertarian set of first principles which stresses the structural similarity of all these kinds of government behavior ${ }^{10}$ and suggests that we need to rule all of them out of bounds if we are to prevent the Leviathan from trampling on us at will. This is decidedly not the approach of the majority of modern economists, however, and it is worth asking what economics has to say about the proper role-if any-of government in combating discrimination.

\section{WELFARE ECONOMICS AND ANTIDISCRIMINATION LAW 11}

A useful normative theory of government regulation must be able to distinguish the conditions under which regulation is appropriate from those

and family breakups. But that general conclusion is of no use in a debate over welfare policy. In such a debate the important question is how many additional fatherless families we will have if we raise $A F D C$ by, say, $\$ 100$ a month. If the number is very small, we can afford to ignore the problem. If it is very large, even hard-core liberals will want to consider other approaches to helping such families. We cannot resolve quantitative questions of this kind by invoking general principles.

Rethinking Social Pulicy 12 (Cambridge, Mass.: Harvard University Press, 1992).

9. Personal communication.

10. Writing in 1962, before the passage of Title VII, Milton Friedman offered an even starker view of this structural similarity:

[Antidiscrimination] legislation involves the acceptance of a principle that proponents would find abhorrent in almost every other application. If it is appropriate for the state to say that individuals may not discriminate in employment because of color or race or religion, then it is equally appropriate for the state, provided a majority can be found to vote that way, to say that individuals must discriminate in employment on the basis of color, race or religion. The Hitler Nuremberg laws and the laws in Southern states imposing special disabilities upon Negroes are both examples of laws similar in principle to [state Fair Employment Practice Commissions].

Capitalism and Freedom 113 (Chicago: University of Chicago Press, 1962) ("Friedman, Capitalism and Freedom").

11. Much of what I wanted to say on this topic turns out to have been covered more cogently by Robert Cooter, "Market Affirmative Action" (forthcoming in the San Diego Law Review symposium on Forbidden Grounds) ("Cooter, 'Market Affirmative Action' "). 
under which it isn't. Economists claim to have such a theory, which goes by a variety of names depending on the level of generality of the subject matter: public finance, welfare economics, cost-benefit analysis. On close examination, these theories turn out to be more fraught with difficulties than many of us would like to admit, but they are the standard analytical tools of the economics profession.

The theory of market failure, as developed in modern welfare economics, is the traditional basis economists use to decide when governmental action is appropriate. Market failures may occur for a variety of reasons, including monopoly, public goods, and externalities, ${ }^{12}$ and in such situations, economic theory suggests that government intervention can be welfare-enhancing, although the definition of welfare-enhancing finesses a lot of the objections that a libertarian like Epstein would raise.

The original proponents of Title VII and other antidscrimination laws did not argue for them using any of the standard justifications that welfare economics offers for government intervention. This may mean that there are no monopoly, externality, or public goods problems inherent in labor market discrimination. Or it may mean that the original proponents of such laws had other matters-like equity or justice-on their minds rather than economic efficiency; or perhaps they simply didn't find the thetoric of welfare economics particularly compelling or useful in making the case for antidiscrimination laws.

Does the relative lack of welfare-economic arguments for Title VII imply, as Robert Cooter puts it, that economic theory is "identified exclusively with abolition [of antidiscrimination laws], in which case the defenders of antidiscrimination laws . . . will feel compelled to oppose economics"? ${ }^{13}$ I agree with Cooter that the answer is no, for two reasons.

First of all, it is possible to make efficiency arguments for Title VII: John Donohue has been associated with several ingenious efforts of this kind. Using a dynamic argument, he shows that Title VII might actually be economically efficient because it speeds up the process of moving to the

12. Economies of scale may make it possible for a single seller to produce all the output demanded by the market at a lower cost than any group of more than one seller. This kind of "natural monopoly" (as is allegedly the case in certain kinds of public utilities or railroads) is one setting in which economics suggests that governmental regulation of some kind may be appropriate to keep prices at a lower level than a monopolist would charge.

Public goods are distinguished from normal private goods in that the former are "nonrival" (when the government protects me from foreign attack, it does not reduce your consumption of national defense) and "nonexcludable" (there is no way to prevent me from benefiting from national defense expenditures, so I have no incentive to pay for them).

Finally, externalities occur when one person's behavior influences another's utility in ways that are not reflected in market transactions. The classic example is smoke from a factory polluting the air downwind that is breathed by others. If the air is treated as a free resource, factory owners see (virtually) no cost to dumping unlimited quantities of smoke into it. Regulation of some sort is often suggested as a means of curbing externalities of this kind.

13. "Market Affirmative Action" at 5. 
efficient, nondiscriminatory equilibrium. ${ }^{14} \mathrm{He}$ has made some back-of-theenvelope calculations about the costs and benefits of the law which suggest that it could actually be welfare-enhancing in the strict sense that economists use that term. ${ }^{15}$ There have also been some attempts to argue that statistical discrimination ${ }^{16}$ is inefficient (and that intervention to correct it can therefore be justified on narrow economic grounds). ${ }^{17}$

These narrowly economic defenses of Title VII are worth making, especially because of their thetorical power against criticisms by some law and economics scholars. But my view is that the case for Title VII doesn't ultimately depend on whether the law is economically efficient. I think the law is designed to make society somewhat more fair or just, not to improve the allocation of resources. This does not mean that we should ignore the costs of antidiscrimination laws, however, and it is here that economics can inform the policy debate in a second way.

Suppose society decides it wants more equity or justice or fairness in the labor market. Regardless of whether this decision is efficiency-enhancing, there will generally be more than one way of achieving the desired level of equity. Some of these means will be more costly than others, and even if they have little to say about the ends of policy, economists can serve a useful role in devising appropriate means to implement it. ${ }^{18}$

14. "Is Title VII Efficient?" 134 U. Pa. L. Rev. 1411 (1986). Becker's model of employer animus-which is the most widely used economic model of discrimination-suggests that discriminators end up paying for indulging in their preferences to not associate with groups they don't like. Because they hire high-cost whites instead of lower-cost black workers, they earn lower profits than a nondiscriminator would. This means that nondiscriminatory employers will have a cost advantage over their discriminatory comperitors. And as long as there are discriminatory employers around, production will not be efficient, because it will be possible for the nondiscriminatory employers to buy the assets of the discriminatory firms, end discrimination, and make a profit in doing so by lowering costs. Donohue's key insight is that discrimination is a disequilibrium phenomenon because it is inefficient; if Title VII can help speed up the transition to the efficient long-run equilibrium by getting discriminatory employers out of the market faster than they would otherwise choose to exit, then the law can increase efficiency.

15. "Advocacy versus Analysis in Assessing Employment Discrimination Law," 44 Stan. L. Rev. 1583 (1992).

16. A loose definition of statistical discrimination might be the use of an observable variable such as race or gender as a proxy for a relevant but unobservable variable like productivity, with which it is believed to be correlated.

17. See, e.g., Stewart Schwab, "Is Statistical Discrimination Efficient?" 76 Am. Econ. Rev. 228 (1986); and Shelley Lundberg \& Richard Startz, "Private Discrimination and Social Intervention in Competitive Labor Markets," $73 \mathrm{Am}$. Econ. Rev. 340 (1983). In the Lundberg-Startz model, e.g., employers use stereotypes in making employment decisions and treat all minority applicants as low-productivity workers. Knowing they will be judged by the "average" or stereotype for their group and not their own educational achievement, minority workers correctly reason that additional education will not do them much good, and thus invest in less education. A law forbidding decisions on the basis of stereotypes, as Title VII arguably does, could thus increase personal investment in education and lead to a better outcome for both workers and employers.

18. This is a major theme of Cooter's article-which provides specific examples in the context of employment discrimination-and of Steven Rhoads's book The Economist's View of the World (Cambridge: Cambridge University Press, 1985). 
Economists do not have a solution to the problem of how to make social choices that respect the preferences of individuals and still obey certain desirable principles (rationality, nondictatorship, and so on). ${ }^{19}$ In the absence of a good method for making social choices, one alternative is to muddle through in a pragmatic, ad hoc fashion. The other is to conclude that collective choices should not be made at all, or at least that the main institution of collective choice-government-should be limited to a tiny domain. Purists may prefer this Epsteinian view. But I believe most economists would agree with the philosopher/economist Amartya Sen, who wrote, "while purity is an uncomplicated virtue for olive oil, sea air, and heroines of folk tales, it is not so for systems of collective choice."20

\section{THE HISTORICAL ROLE OF THE STATE IN ENFORCING DISCRIMINATION}

One of the lynchpins in Epstein's case against Title VII is his contention that the legacy of segregation and discrimination against blacks, which he repeatedly deplores, was created and sustained only by the active intrusion of government into private contractual relations. If the federal judiciary had only drastically limited southern state and local governments' use of their police powers to enforce discrimination in the period after Reconstruction, Epstein claims, private markets would have eliminated discrimination on their own. In Epstein's view, the tragedy of the 1964 Civil Rights Act is that it went too far. Instead of just striking down governments' powers to require discrimination, a move Epstein applauds, Title VII went on to mandate nondiscrimination, leading to our present sorry state of affairs.

According to Epstein's version of postbellum legal history, mandatory discrimination laws were foisted on unwilling firms and workers by populists whose appeal to white workers allowed them to dominate state legislatures. In this view, Jim Crow laws-backed by the coercive power of the state, with its monopoly (?) on the use of force-required firms to discriminate in labor markets; only a few firms would have refused to hire blacks in the absence of laws forcing them to do so.

There is a certain logic to Epstein's position. Suppose that black and white workers are equally productive but employers dislike blacks and prefer white workers. This prejudice should be reflected in lower demand for black workers, lower wages paid to blacks, and fewer blacks hired. But this is not the end of the story. As long as there are some nonprejudiced entrepreneurs

19. In fact, Kenneth Arrow's famous impossibility theorem demonstrates that under reasonable conditions, there is no way to make such choices. See Arrow, Social Choice and Individual Values (New York: Wiley, 1951). 1970).

20. Amartya Sen, Collective Choice and Social Welfare 200 (San Francisco: Holden-Day, 
interested only in making as much profit as possible, they should quickly appreciate that by hiring blacks (even an all-black workforce), they can lower their costs substantially. Black-white wage differences should be competed away, as the few nonprejudiced firms bid up the wages offered to blacks. $^{21}$

Clearly, this is not what happened in the American South. ${ }^{22}$ Black wages remained substantially lower than wages for whites in comparable jobs. Discrimination did not vanish. The question is, Why not? According to Epstein, what prevented the forces of greed from working to equalize black wages in the Jim Crow era was not the failure of economic incentives in the face of powerful tradition, custom, and culture but the direct intervention of governments. ${ }^{23}$

What is the evidence for this position? Serious students of southern history disagree on the extent to which segregation and discrimination were mandated by government. For example, John Cell gives some compelling evidence $^{24}$ that Epstein-drawing entirely on legal decisions and a smattering of the secondary literature-does not provide in his own defense. Ironically, Cell's "soft Marxist" approach dovetails nicely with Epstein's libertarian vision: In both, the apparatus of the state is captured by private/ class interests to serve their own ends. The difference is that Cell's analysis

21. This is a loose paraphrase of the theory developed by Gary Becker in The Economics of Discrimination (Chicago: University of Chicago Press, 1957; 2d ed. 1971), the work that first used economic theory to address race discrimination. The key insight of Becker's theory is that employers must bear at least some of the costs of their discriminatory preferences when they substitute higher-cost white workers for equally productive and cheaper blacks. Kenneth Arrow succinctly summarized the problem with Becker's model, however: "it predicts the absence of the phenomenon it was designed to explain." Arrow, "Some Mathematical Models of Race in the Labor Market," in A. H. Pascal, ed., Racial Discrimination in Economic Life 192 (Lexington, Mass.: Lexington Books, 1972).

22. The most compelling piece of evidence on the economics of segregation in southern labor markets is the work of James Heckman \& Brook Payner, "Determining the Impact of Federal Antidiscrimination Policy on the Economic Status of Blacks: A Study of South Carolina," $79 \mathrm{Am}$. Econ. Rev. 138 (1989). Epstein suggests that the existence of a law barring blacks from certain kinds of employment in textiles explains these results. However, no such law existed in other southern states, yet the same patterns were observed elsewhere.

Epstein cites some evidence of business resistance to mandatory segregation laws (especially for railways and streetcars). But this evidence is itself questionable. Barbara Y. Welke, "'All The Women Are White; All the Blacks Are Men,' Or Are They? Law and Segregation on Common Carriers, 1855-1914" at 87-90 (American Bar Foundation Working Paper 9215, 1992), finds evidence that many common carriers did support mandatory segregation. What's more, Epstein does not offer good evidence that employers were opposed to segregation, as required by his theory, or that labor market discrimination was only sustained by government intervention.

23. Economists James Heckman and J. Hoult Verkerke claim that the "informal . . Southern code was enforced primarily through social and economic pressure with the threat of private violence should less severe sanctions fail." "Racial Disparity and Employment Discrimination Law: An Economic Perspective," 8 Yale L. \& Pol'y Rev. 276, 278 (1990), quoted in Epstein at 97.

24. The Highest Stage of White Supremacy: The Origins of Segregation in South Africa and the American South (Cambridge: Cambridge University Press, 1982). 
is based on a deep and thorough program of historical research. Epstein can only allude to the vast power of the state to compel segregation through the use of zoning laws, safety regulations, and so on as clubs held over the head of firms that offered higher wages to blacks or hired black workers in segregated industries. Despite assertions that such weapons were available, Epstein provides not a single example of their actual use to enforce discrimination. ${ }^{25}$ Rather, their importance is derived a priori from a libertarian notion of what the Leviathan is capable of.

By contrast, Alexis de Toqueville noted in the 1830s:

[A]mong the ancients ... the freed [slave] bore so entire a resemblance to those born free that it soon became impossible to distinguish him from them. The greatest difficulty in antiquity was that of altering the law; among the moderns it is that of altering the customs, and as far as we are concerned, the real obstacles begin where those of the ancients left off. . . . At the present day the legal barrier which separated the two races is falling away, but not that which exists in the manners of the country; slavery recedes, but the prejudice to which it has given birth is immovable. ${ }^{26}$ (Emphasis added)

Anthropologist Hortense Powdermaker's fascinating ethnography of a Mississippi delta town in the 1930s likewise stresses the social and cultural bases for segregation that operated entirely outside the formal law and were enforced by no governmental authority. For example,

a social prohibition to which great weight is attached is that which forbids addressing a Negro as "Mr.," "Mrs.," or "Miss." [whites will use "professor" or "doctor" but never "Mr."] To violate this strong taboo is to arouse the resentment, suspicion, fear, which attend the breaking of taboos or customs in any culture. If a Melanesian is asked what difference it would make if he failed to provide a feast for his dead maternal uncle, or if he broke the rule of exogamy, his attitude is one of complete bewilderment and strong fear at the mere suggestion. If a member of his community should actually commit such a breach, he would resent it as an invitation to general disaster. The title taboo is sensed as equally essential to the status quo in Mississippi. To question either is to question the whole system; to violate either is to violate, weaken, endanger, the entire status quo. ${ }^{27}$

25. He does cite a South Carolina law that required segregation in certain jobs in textile plants. But readers of this journal will not need to be told that there is a big difference between law on the books and law in action, and Epstein never moves from the former to even the most primitive version of the latter.

26. Alexis de Tocqueville, Democracy in America 357-59 (New York: Alfred A. Knopf, 1963). Tocqueville was of course writing about a period 70 or 80 years before the time Epstein discusses, but his insight that it was "custom," not law, that was the root of the race problem remains apposite.

27. Hortense Powdermaker, After Freedom: A Cultural Study in the Deep South 44-45 (New York: Atheneum, 1939; 2d ed. 1967). 
No formal statute or regulation governed forms of address in Indianola, Mississippi. No state action was involved in maintaining these or countless other customs Powdermaker vividly describes. If "law" is at work here, it is a local and informal law, enforced by custom and the KKK, not the state. ${ }^{28}$

Economists James Heckman and Brook Payner came to a similar conclusion after examining the lack of black penetration into the South Carolina textile industry between 1910 and 1970 . Through more than 50 years of wars, depressions, and booms, blacks remained a constant (and negligible) fraction of total employment in textiles. Then, in 1965-the year Title VII went into effect-their participation began a sudden and dramatic rise.

How are we to explain this fact? Although there was a law requiring certain kinds of job segregation in textiles, Heckman and Payner, after an exhaustive examination of the quantitative and qualitative evidence, conclude that the law was simply not enforced beyond the first few years after its passage. ${ }^{29}$ Instead, they describe a regime in which segregation was maintained by a set of powerful norms and customs, sustained by threats (and actual use) of violence against potential norm breakers. ${ }^{30}$

28. In an ironic passage, Epstein attacks two economists, James Heckman and J. Hoult Verkerke, for being too anthropological in arguing for the importance of extralegal forces in maintaining Jim Crow.

In order to sustain the basic position that cultural and social norms are sufficient to sustain Jim Crow, it becomes necessary to ... ask whether Jim Crow would have survived if southern whites had voluntarily relinquished their control over the ballot, the police force, the courts, and other instruments of state domination. . . . The tighter the social cartel against blacks under Jim Crow, the larger the returns to new [nondiscriminatory] entry in the marketplace, notwithstanding a social consensus in the opposite direction. In speaking of the same problem in connection with litigation in Japan, J. Mark Ramseyer and Minoru Nakazato have demonstrated in the Japanese context that these community norms are fragile in the sense that a single outsider who has little to fear from ostracism can undermine them by going to court. . . J Japan is regarded as a closed society, perhaps even more so than the Old South. If the single marginal entrant can change the social balance of power in the one case, then it can do so in the other. (At 97)

What's remarkable here is the sense that the fragility of culture in the face of economic incentives is simply a principle that, once established, can be applied to the Old South without the need for supporting evidence of any kind.

Moreover, Heckman and Verkerke do not say that cultural and social norms were sufficient by themselves to sustain Jim Crow, merely that they played an important role in sustaining segregation and that the law was insufficient by itself.

29. In addition, the pattern of segregation began before the law was passed and continued long after the law was struck down as unconstitutional, which further argues against the importance of the law as a bulwark of segregation. See Donohue, 44 Stan. L. Rev. at 1583-95 (cited in note 15).

30. This accords well with the views of the distinguished Southern historian Joel Williamson, who writes:

Violence and the great threat of violence was one way in which [whites] sought to lower the self-esteem of blacks and thus render them more controllable on the way to their demise. We could never catalog and describe, nor even count all of these instruments of discrimination. ... Two of [the] tools used to reduce, and hence, to manage blacks were disenfranchisement and segregation. These tools were often the subject of laws and legalities. ... Perhaps . . . because these laws and legalities were so amenable to the kind of verbal reduction traditionally favored by scholars. . . . they have been so much empha- 
In short, Epstein is correct to raise the question of the relative importance of state action, as opposed to culture, tradition, and informal law, in keeping black wages low and black workers segregated. However, he is incorrect in presuming the decisive primacy of state intervention. There is some support for Epstein's position, but there also seems to be an important role exerted by forces outside of government that Epstein's libertarian blinders will not allow him to see. ${ }^{31}$ Again, the fundamental questions are empirical: How much extra leverage were whites able to exert by virtue of their control of the official state apparatus and laws? Was governmental enforcement of mandatory segregation necessary? Or could segregation have survived (especially after it became entrenched by the 1910s) without much governmental backing? Economic theory can suggest some of the forces at play here, but we're expecting too much of economics if we ask it to give the final answers to these questions, as Epstein supposes it can.

"Ultimately," writes Joel Williamson,

[I]t was not the myriad and ingenious legal stratagems of Southern white leadership that disenfranchised and depoliticized Negroes in the South after Reconstruction. . . . Certainly laws were important to the process ... [but] more vitally important than the laws were the economic, the physical, and especially the social and psychological sanctions imposed on blacks. ${ }^{32}$

\section{EPSTEIN AS ECONOMIST}

One of the most curious things about Epstein's book is the virtual absence in it of any discussion of the vast empirical literature on the economics of employment discrimination. For example, Glen Cain's masterful survey of the theoretical and empirical literature ${ }^{33}$ is not even mentioned. One could read Epstein from cover to cover without realizing that a substantial majority of economists who study labor markets believe discrimination is a serious and persistent problem.

sized by students of race relations. [They are, however,] only a small and not totally representative portion of reality.

The Crucible of Race: Black-White Relations in the American South since Emancipation 224 (Oxford: Oxford University Press, 1984) ("Williamson, Crucible of Race").

31. Even Milton Friedman-the eminence grise (eminence bald?) of the Chicago School of Economics, whose Capitalism and Freedom (cited in note 30) is a paean to libertarianismnotes in a different context: "To a considerable extent . . . in the [Indian] caste system, ... restrictions [on employment opportunities] were enforced by general social customs rather than explicitly by government." Id. at 138.

32. Williamson, Crucible of Race 247.

33. Cain, "Economic Analysis" (cited in note 2). 
In chapter 2, Epstein briefly discusses the leading economic models of discrimination. The chapter also analyzes (and dismisses) three empirical studies of discrimination, but these seem to have been selected almost at random and two of them have nothing to do with discrimination in employment. ${ }^{34}$ Chapter 12 , which assesses the effects of Title VII, does deal with some of the economic literature on the subject. And there are some references to economists such as James Smith and Finis Welch who have argued that it was increases in years or quality of education-and not government intervention - that was responsible for black relative income growth in the decade starting around 1965.

Epstein's discussion of the Urban Institute's study of discrimination in Washington and Chicago ${ }^{35}$ provides an example of his idiosyncratic approach to empirical work. Borrowing from a technique long employed in fair housing litigation, ${ }^{36}$ the study used matched pairs of testers-one black and one white-who were carefully selected and trained and then sent to the same employers to apply for jobs. If testers who are "identical except for race" are treated differently, this is considered to be evidence of discrimination. This is exactly what these studies found. In Washington and Chicago, for example, the Institute conducted 438 audits using matched pairs of black and white testers. Overall, the 'two testers were treated the same in 350 (79\%) of the tests, the white tester was favored in $65(14.8 \%)$ and the black tester was favored in $25(5.7 \%){ }^{37}$

Epstein obviously wishes to call into question the significant evidence of discrimination found in the Urban Institute (UI) study. While there are a number of legitimate analytical questions that can be raised about this pioneering work, ${ }^{38}$ much of Epstein's fivefold critique strikes me as somewhat dubious.

34. One is a study of discrimination in the pricing of baseball cards (Clark Nardinelli \& Curtis Simon, "Customer Racial Discrimination in the Market for Memorabilia: The Case of Baseball," 105 Q.J. Econ. 575 (1990)); the other examines disparities in the prices quoted to test buyers of new cars (Ian Ayres, "Fair Driving: Gender and Race Discrimination in Retail Car Negotiations," 104 Harv. L. Rev. 817 (1991)).

35. Margery Austin Turner, Michael Fix, \& Raymond J. Struyk, Opportunities Denied, Opportunities Diminshed: Discrimination in Hiring (Washington: Urban Institute Press, 1991).

36. See, e.g., Havens Realty Corp. v. Coleman, 445 U.S. 363 (1982) (granting standing to fair housing testers to sue for damages).

37. There are statistical and conceptual problems with aggregating the data, but they are presented in this form for expository convenience. For a more detailed analysis, see James Heckman \& Peter Siegelman, "The Urban Institute's Audit Studies: Their Methods and Findings," in Michael Fix \& Raymond Struyk, eds., Clear and Convincing Evidence: The Measurement of Discrimination in America (Washington: Urban Institute Press, 1992) ("Heckman \& Siegelman, 'Urban Institute's Audit Studies' ").

38. Along with its similar study of discrimination against Hispanics-Harry Cross et al., Employer Hiring Practices: Differential Treatment of Hispanic and Anglo Job Seekers (Urban Institute Report 90-4; Washington: Urban Institure Press, 1990)—the Urban Institute's work represents the first serious attempts to use paired audits to investigate hiring discrimination. For a critical but appreciative assessment of the results, see Heckman \& Siegelman, "Urban Institute's Audit Studies." 
After briefly describing the UI's methods and conclusions, Epstein begins his attack by suggesting that the "Institute's political conclusions far outstrip its data" (at 56). Labeling your opponent's views as "political" is generally not a good way to begin a serious intellectual discussion. ${ }^{39}$

Epstein's second criticism is that the firms audited by the UI were obtained from a sample of help-wanted ads in major newspapers for entry-level positions, which are not representative of all jobs in the economy. This is perfectly correct, and we should be very cautious in extrapolating the UI's results to the market for college faculty or corporate executives. But this critique doesn't make the evidence irrelevant for the kinds of jobs (low skill, entry level) that are appropriate for typical high school graduates, which is who the testers were pretending to be. Besides, if there is any bias introduced by sampling only firms that advertise in newspapers, it seems plausible that is a bias against finding discrimination. After all, firms wishing to discriminate would probably prefer to hire by word of mouth rather than using advertisements that draw applicants they wish to avoid hiring. ${ }^{40}$

Epstein's third objection is that the results are contaminated by the Urban Institute's "political stake in the outcome" (at 57), which may have led testers to act in such a way as to produce evidence of precisely the discrimination they were looking for. Again, Epstein raises a legitimate point but then exaggerates its importance. "Experimenter effects" (in which "the experimenter is not simply a passive runner of subjects, but can actually influence the results" of an experiment ${ }^{41}$ ) are well known in social psychology, and probably do represent a weakness in the UI's method, although there were good reasons why the testers were not kept in the dark about the purposes of the study. But even if a pro-discrimination bias is introduced by the experimenter effects, there is still the empirical question about how much such effects actually matter. ${ }^{42}$

39. Could Epstein have confused the Urban Institute-a nonprofit, nonpartisan, public policy research institution along the lines of the Brookings Institute - with the Urban League, the civil rights advocacy group? This might account for some of his suspicion of the study's findings.

40. Heckman \& Siegelman, "Urban Institute's Audit Studies," provide some further references on this point.

41. Gardner Lindzey \& Elliot Aronson, 2 The Handbook of Social Psychology 66 (2d ed. Reading, Mass.: Addison-Wesley, 1975). For a more extensive treatment, see Robert Rosenthal, Experimenter Effects in Behavioral Research (2d ed. New York: Irvington Publishers, 1976).

42. It should be pointed out that the UI testing protocols suggest that strenuous efforts were made to keep the testers as neutral and objective as possible.

Furthmore, Epstein ignores all of the baises against finding discrimination in the UI study. The antidiscriminatory bias of relying on newspaper advertisements as a sampling frame was mentioned earlier. To take another example, suppose that firms use probationary hiring periods and on-the-job evaluation as substitutes for preemployment screening. (Such personnel policies seem to be quite widespread, although little is known about their extent. See, e.g., Erica Groshen \& Eng Send Loh, "What Do We Know about Probationary Periods?" (Federal Reserve Bank of Cleveland, 1993).) If it exists, discrimination will then show up in differential firing rates rather than in differences in offers made to identical testers. Since the UI studies do not actually place testers on the job and examine their subsequent treatment by 
In a classic use of the lawyer's tactic of arguing in the alternative, Epstein's next line of attack shifts grounds dramatically. Instead of claiming that the UI results do not show discrimination, he argues that even if they do, there may be good reasons for firms to discriminate (e.g., if a segregated workforce is more productive because of lower worker tensions or better morale). While it is conceivable that segregated workplaces are indeed more productive, I am not aware of a single piece of evidence that this is actually true. If Epstein wants to assert this empirical proposition, it seems to me that the burden should be on him to prove it. This is especially true because making employment decisions on the basis of race is illegal, regardless of the consequences for productivity. (Of course, Epstein wants to make the case that employment discrimination laws should be eliminated, but that is irrelevant to the empirical finding of discrimination uncovered in the UI study.)

Finally, Epstein suggests that even if some firms do discriminate, this doesn't impose serious costs on black applicants because they can easily find other employers who do not care about race. ${ }^{43}$ Epstein's analysis here might be valid if potential employees could costlessly find nondiscriminatory employers. But coming from someone who repeatedly decries the lack of attention paid by supporters of Title VII to search costs and imperfect information, Epstein's assumption that the only search costs we should ignore are those of black job seekers rings a little hollow. ${ }^{44}$

This one-sided treatment of search costs-indeed, any costs of discrimination-echoes throughout the book: in a truly free market, Epstein claims, it would be "as if discrimination didn't exist" because victims of discrimination could always find an employer who didn't discriminate and work for him (at virtually no cost in terms of lower wages or lost opportunities). But this assertion is not supportable as a matter of economic theory. In fact, the UI results suggest that "with identical fixed costs of job search for blacks and whites, as well as a common wage offer distribution, ... blacks would have lower reservation wages and lower accepted wages than whites.

employers, they will be powerless to detect this kind of discrimination, as Heckman \& Siegelman, "Urban Institute's Audit Studies," point out.

43. What relative wages "should we expect to observe for blacks and whites, equally qualified, given the [Urban Institute] data," Epstein asks, rhetorically (at 58). "The answer is, there will not be much difference-if any at all" because "while testers apply for jobs in matched pairs, real job seekers look for those employers who will offer them the most favorable deals. Black workers will gravitate to firms that afford them a preference or to those that are indifferent in matters of race."

44. Substitute "discrimination" for "complying with Title VII" in the following paragraph and you immediately see the asymmetry in Epstein's views. "Employers (and employees) may adopt strategies to mitigate the costs of complying with Title VII, and this is all to the good. But mitigation does not restore the market to the status quo ante of the unregulated world. Mitigation costs money [more precisely, resources of some kind], so after the appropriate steps are taken," the employer is worse off than he would have been if the need to mitigate had never arisen (at 181). This is nothing more than a definition of opportunity cost, but it appears that only the costs imposed by Title VII, and not those caused by discrimination, are cognizable in Epstein's worldview. 
Wages for working blacks would be lower than wages observed for working whites, even if employers made identical wage offers to accepted blacks and whites" but discriminated against blacks at the hiring stage. ${ }^{45}$ In other words, discrimination does impose economic costs on its victims (which should come as no surprise), and Epstein is wrong simply to assume these away.

\section{EPSTEIN AS LAWYER: DISPARATE TREATMENT}

While the first half of Forbidden Grounds offers theoretical, historical, and quasi-economic analyses of discrimination, in the second half Epstein takes on the structure of antidiscrimination laws themselves. Here, he is slightly more reasonable than in the first half, although there is still plenty to raise the hackles of most readers. At the very least, readers of LSI will probably be annoyed at Epstein's tendency to assume that the effects of laws can simply be deduced by simple applications of "price theory,"46 without the need to conduct any empirical work.

Chapter 9 takes up the disparate treatment doctrine that is the mainstay of most cases brought under Title VII.47 (Disparate treatment is sometimes referred to as deliberate or intentional or explicit discriminationoutright refusal to accept applications from blacks or explicitly closing off certain jobs to women. ${ }^{48}$ ) While critical of Title VII for interfering with private preferences and the efficient operation of markets, Epstein is surprisingly tolerant of the disparate treatment doctrine. At one point, he writes: "In practice, title VII would be a very modest shadow of itself if plaintiffs were confined to the disparate treatment framework" (at 166). ${ }^{49}$

45. Emphasis added; Heckman \& Siegelman, "Urban Institute's Audit Studies," at 219 (cited in note 37 ). In other words, black workers will be more likely to accept any given wage offered by an employer than will whites, because blacks know they will have a hard time finding another offer due to hiring discrimination.

46. "Price Theory" is the Chicago School's term for 1950s/60s vintage microeconomic theory as exemplified in George Stigler's text, The Theory of Price (New York: Macmillan, 1946). It has been largely superseded in the economics profession by the new economic theory of asymmetric information and strategic rivalry (see, e.g., Eric Rasmusen, Games and Information (Oxford: Basil Blackwell, 1989)), which often yields diametrically opposite conclusions.

47. John Donohue \& Peter Siegelman, "The Changing Nature of Employment Discrimination Litigation," 43 Stan. L. Rev. 983 (1991) (disparate impact cases account for only a small share of all employment discrimination claims).

48. The distinction between disparate treatment and disparate impact (facially neutral policies that have an unfavorable effect on a protected class) is discussed below.

49. "Although the costs of trying disparate treatment cases are substantial," Epstein claims-without any serious evidence-

on balance I have little doubt that these costs, had they been made explicit in the early debates, would have been regarded as acceptable by the Congress that passed the 1964 act. As a practical compromise, moreover, a limitation of Title VII race cases to individual disparate treatment cases would honor the original intentions of the statute while removing most of its heavy costs. These cases are not especially controversial today. (At 181) 
This last assertion reveals something interesting about the difference between law and the social sciences as intellectual disciplines. Law professors worry about the difficult or novel legal issues raised in "important" cases. But there are relatively few "important" cases, and they are not at all representative of the vast majority of "everyday" cases. Contrary to Epstein's assertion, $85 \%$ of filed cases contain only garden-variety disparate treatment allegations. ${ }^{50}$

Epstein's criticism of disparate treatment doctrine is essentially twofold. First, he argues that (in the absence of gross evidence such as "Whites Only" signs), the law requires costly, difficult, and error-prone inquiries into what motivated the employer's decision that is the subject of the dispute. Was the plaintiff fired because she was black and the employer didn't like black people (as the plaintiff claims)? Or because she was "incompetent," as the defendant claims? To resolve a lawsuit, the court must, somehow, answer these questions. ${ }^{51}$ And the process of resolution will always entail costs, sometimes large ones, even when courts reach the correct verdict, which they don't always do.

Note that this critique is not directed at the disparate treatment doctrine itself but rather at the idea that courts should have any role in resolving employment discrimination disputes. Epstein is clearly right that the law is much better at dealing with obvious instances of overt racism than with subtler ones. And of course, racist employers are not fools, and they soon learn that they had better take down their "Whites Only" signs, even (especially) if they don't change anything else about their employment practices. And he's also right to acknowledge that legal decision making is costlyand sometimes wrong. But that is only the beginning of the analysis, not the end of it. The market is costly and sometimes wrong, too. The strong political support for civil rights legislation of all kinds (including the 1991 Civil Rights Act, which explicitly overturned several Supreme Court decisions that had weakened certain provisions of Title VII) reflects society's judgment that markets don't always get it right.

50. Donohue \& Siegelman, 43 Stan. L. Rev. The distorted perceptions caused by the focus on cases with published opinions is documented in Peter Siegelman \& John Donohue, "Studying the Iceberg from Its Tip? An Analysis of Differences between Published and Unpublished Federal Employment Discrimination Cases," 24 Law $\mathcal{E}^{3}$ Soc'y Rev. 1133 (1991). See also Theodore Eisenberg \& Stewart Schwab, "What Shapes Perceptions of the Federal Court System," 56 U. Chi. L. Rev. 501 (1989).

51. The formal outline for how to prove a disparate impact case (articulated in McDonnell Douglas v. Green, 411 U.S. 792 (1973)) provides for a three-part standard: first the plaintiff must prove that (s)he is a member of a class of persons protected under Title VII and that she was fired or not hired from a job for which she was qualified; second, the defendant is given a chance to justify his behavior as motivated by factors other than race; finally, the plaintiff gets a chance to show that the employer's stated explanation is simply a pretext to cover up his use of race. About this burden shifting exercise, Epstein has this to say: "I doubt that anyone could come up with a simpler set of rules that would capture the full set of relevant considerations under the statute in a clearer and more logical form than was done in McDonnell Douglas and its progeny" (at 168). 
In other words, we do need to consider the costs of Title VII, but we also need to account for its benefits. Once again, this raises empirical questions, which fundamentally cannot be answered on the basis of theory alone. Some defenders of civil rights have been as guilty as Epstein has in suggesting that we ignore one side of the cost/benefit equation, but that is not grounds for then ignoring the other side. ${ }^{52}$

Measuring-or even conceptualizing-these costs is very difficult. One of the main weaknesses of most economic accounts of discrimination-Epstein is unfortunately not alone here-is that they implicitly ignore any "pain or stigma felt by the victim. A lower price for one's services appears to capture the extent of victimization" in these analyses. ${ }^{53}$ This is not an inherent flaw, however: as Donohue demonstrates in his assessment of Title VII, it is possible to roughly estimate what the dignitary harms of discrimination might be and include them in a rigorous economic analysis of the law. ${ }^{54}$

Interestingly, as Epstein himself demonstrates, many proponents of the 1964 Civil Rights Act believed (or claimed) that it was actually a pro-market law that would end the "waste" that results from "the failure of our society to extend job opportunities to the Negro." 55 And at least some business people today seem to view the law much as its early supporters did-as an encouragement to do what is morally right and to follow sound business practices. ${ }^{56}$ If true, this suggests that there might even be an underlying efficiency justification for the law as a prod to firms to improve their personnel management.

Epstein's second major criticism of disparate treatment doctrine is that it has moved away from the color-blind notions of its original drafters to a special emphasis on protecting only certain groups. As he puts it:

McDonnell Douglas [the Supreme Court case cited above, note 51] ... marks a ... shift in the basic orientation of antidiscrimination laws. On its face the statutory language falls within the tradition of colorblind laws [forbidding discrimination] against any individual because of

52. For an early effort that is cognizant of both the costs and benefits of the law, and arrives at a much more balanced view than Epstein's, see Owen Fiss's now classic "A Theory of Fair Employment Laws," 38 U. Chi. L. Rev. 235 (1971).

53. Cain, "Economic Analysis" at 710 (cited in note 2).

54. Donohue, 44 Stan. L. Rev. (cited in note 15).

55. H. Rep. no 9014, 88th. Cong. 1st sess., 1963, at 149 (views of additional Republican sponsors), quoted in Epstein at 162.

56. "I think the law becomes a secondary element. I mean, if the law wasn't there, we'd still be doing what we're doing because we think it's the right thing to do and our policies and procedures are based on what we feel are sound personnel practices." Anonymous corporate personnel officer, describing EEO law, as quoted in Lauren Edelman, Howard S. Erlanger, \& John Lande, "Internal Dispute Resolution: The Transformation of Civil Rights in the Workplace," 27 Law \& Soc'y Rev. 497, 515 (1993). See also Frank Dobbin, Lauren Edelman, John W. Meyer, \& W. Richard Scott, "Equal Opportunity Law and the Construction of Internal Labor Markets," 99 Am. J. Soc. 396 (1993). 
race, color, religion, sex, or national origin. But the ... formula in McDonnell Douglas changes the substantive rule, for it is geared solely toward workers from a "racial minority." ... [T] [Tere is no reason to shift from the color-blind statutory language to the race-specific protected class in articulating the cause of action. It is perfectly consistent with both the language and purpose of Title VII to make the first element of the prima facie case outlined in McDonnell Douglas that the plaintiff, any plaintiff, was "qualified" but nonetheless was passed over for someone of a different race. (At 176)

It is not obvious that this doctrinal shift is as bad as Epstein seems to think it is, or even that color blindness was ever the principle underlying Title VII. ${ }^{57}$ But there is a more fundamental problem: There is good reason to think that this shift from color blindness to "protected class" simply doesn't mean what Epstein says it does. True, McDonnell Douglas did require that the plaintiff show membership in a "protected class" as part of establishing a prima facie case of discrimination. But in a subsequent decision not cited by Epstein, the Supreme Court held that the protected class included essentially everyone, so that white males are indeed covered under Title VII as Epstein would like them to be. ${ }^{58}$

In sum, Epstein is absolutely correct to suggest that there are costs to having an antidiscrimination law. This will come as no news to economists, because the notion of opportunity costs and trade-offs means that there are costs to every policy. But the story doesn't-or shouldn't—end there. It is not enough merely to list what those costs include and to assert that they are large. A good economic analysis requires that you go out and measure the costs and then compare them against the benefits, which have been measured with equal scrupulousness. Epstein doesn't even attempt to mount the kind of back-of-the-envelope calculation of costs and benefits that can be useful in giving a rough sense of their relative magnitude. ${ }^{59}$

57. Fiss, 38 U. Chi. L. Rev., argues-in my view convincingly-that Title VII was never meant to be a color-blind statute; instead, he suggests, it should be thought of as a legitimate attempt to extend a (rather limited set of) benefits to black citizens.

58. McDonald v. Santa Fe Trail Transp. Co., 427 U.S. 273 (1976). See also Alfred Blumrosen, "Strangers No More: All Workers are Entitled to 'Just Cause' Protection under Title VII," 2 Indus. Rel. L.J. 519 (1978), and George Rutherglen, "Abolition in a Different Voice," $78 \mathrm{Va}$. L. Rev. 1463 (1992) (review of Forbidden Grounds). Whether the body of judicial decisions and administrative enforcement policies has actually treated discrimination against blacks and whites equally seriously is beside the point here, since the argument is one about what the law says, not how it has been enforced.

59. John Donohue's review of Epstein, 44 Stan. L. Rev., provides an excellent example of what this kind of analysis looks like. 


\section{DISPARATE IMPACT}

Epstein reserves his harshest criticism for the disparate impact doctrine, under which a facially neutral employment practice can be deemed discriminatory if it has a disproportionately adverse impact on members of a protected class. For example, an employer who required a high school diploma of all applicants might be subject to liability under the disparate impact standard if it could be shown that fewer blacks than whites had high school diplomas and the practice wasn't justified by "business necessity," as in Griggs ข. Duke Power Company. ${ }^{60}$

Epstein's critique of the disparate impact doctrine has two parts. The first is a narrowly legal attack on the reasoning in the Supreme Court's adoption of the disparate impact decision in Griggs. The language in Title VII makes no reference to either "disparate impact" or "disparate treatment," so in deciding Griggs, the Court had to determine whether Congress intended the statute to prohibit facially neutral employment practices that had an adverse impact on minorities. Epstein presents compelling evidence from the legislative history of Title VII that many of its initial drafters and supporters considered-and rejected-the idea of disparate impact type liability under the law. ${ }^{61}$ In fact, Title VII explicitly allowed certain employment practices (such as seniority systems, merit-based promotions, and professionally developed tests) unless they were "designed, intended or used to discriminate because of race, color." 62 These provisions were added, Epstein argues, precisely to reassure the opponents of Title VII that the statute would not subject employers to disparate impact liability; and yet the Supreme Court construed congressional intent in exactly the opposite way. ${ }^{63}$

I think Epstein is basically right that "the Supreme Court in Griggs perverted both the language and the legislative history" of Title VII (at

60. 401 U.S. 424 (1971). This is a crude version of the facts in the Supreme Court decision that enunciated the disparate impact doctrine. Epstein fails to note the irony that it was the Burger court, hardly noted for its boldness, liberalism, or judicial activism that was responsible for this decision-indeed, the 8-0 opinion was written by Chief Justice Warren Burger himself.

61. For example, Epstein (at 188) quotes Sen. Hubert Humphrey, a leading sponsor of the legislation, in congressional debate: "I would like to make an offer. . . . If the Senator can find in Title VII . . . any language which provided that an employer will have to hire on the basis of percentage or quota related to color ... or race I will start eating the pages one after another, because it is not in there." Since the phrase "disparate impact" didn't exist in 1964, Epstein correctly notes that the debates couldn't crystallize around these exact words; the question whether discrimination could be proved solely by bottom-line statistical results with no reliance on intent was thus never explicitly addressed.

62. Sec. 703(h) of title VII.

63. Much the same argument is made by Michael Gold ("Griggs' Folly: An Essay on the Theory, Problems, and Origin of the Adverse Impact Definition of Employment Discrimination and a Recommendation for Reform," 7 Indus. Rel. L.J. 429 (1985))-whom Epstein doesn't cite. 
197). Even if you believe that poorly reasoned decisions are bad law, regardless of their consequences or results, however, Epstein's criticism loses a great deal of its force when Griggs is considered in light of the succeeding legislative history. After all, the reason courts are supposed to defer to the intent of the legislature is that the former are appointed, nondemocratic institutions which presumably do not reflect the will of the people as closely as their elected representatives do. But as Epstein himself notes, Congress revisited the topic of antidiscrimination law twice (in 1972 and 1991), and both times it endorsed the expansive view of civil rights. ${ }^{64}$ Even if Griggs reflects a misreading of congressional intent and a sloppy job of statutory construction, Congress obviously caught up with, and then surpassed, the Supreme Court's views on disparate impact and other matters. So this part of Epstein's criticism seems largely moot.

Epstein's slap at the legislative history of the 1972 amendments to Title VII also deserves a brief mention. Rather disingenuously, he attacks the legislators for pointing out that "whereas blacks held 10 percent of all jobs, they accounted for 'only 3 percent of all jobs in the high-paying professional, technical, and managerial positions.' There was no effort to adjust these figures to take into account conflating factors: levels of education are not discussed, and more subtle factors are similarly ignored" (at 202).

If Epstein were interested in more than scoring debater's points, he could have looked at Glen Cain's survey article (cited earlier) and noted two things. First, although racial differences do decrease when controls (education, experience, and so on) are added to regressions explaining wages or occupational patterns, a key finding in the literature is that substantial differences remain even when extensive controls are added. It seems wrong for Epstein to fault Congress for failing to consider the evidence (much of which wasn't even available in 1973) that he ignores today.

Moreover, economic theory does not offer us very strong guidance on the control variables that should be included in these regressions. For example, if expectations about labor market discrimination influence the amount or quality of education people choose, ${ }^{65}$ then including education variables in a regression explaining wages will produce downward bias in estimates of

64. Congress indicated its support for the disparate impact theory in the legislative history accompanying its 1972 amendments to Title VII. And the 1991 Civil Rights Act specifically overturned several Supreme Court opinions that cut into the scope of the disparate impact doctrine (Wards Cove v. Antonio, 490 U.S. 642 (1989)) and limited the use of the 1866 Civil Rights Act (Patterson v. McLean Credit Union, 491 U.S. 164 (1989)). In these decisions and others (e.g., General Elec. Co. v. Gilbert, 429 U.S. 125 (1976), holding that discrimination on the basis of pregnancy did not violate Title VII, subsequently overturned by the Pregnancy Discrimination Act of 1978) the Supreme Court actually encouraged Congress to do its job-explicitly confront the issue of civil rights and decide what kind of laws it really wanted. See Ian Ayres \& Robert Gertner, "Filling Gaps in Incomplete Contracts: An Economic Theory of Default Rules," 99 Yale L.J. 87, 129 (1991), for a "penalty default rule" theory of statutory interpretation.

65. See, e.g., Lundberg \& Startz, 73 Am. Econ. Rev. (cited in note 17). 
discrimination, as Cain and others have long since pointed out. ${ }^{66}$ So while ignoring differences in education, experience, and so on probably overstates discrimination, including these variables may well understate the amount of discrimination detected-it is not obvious which is the proper approach.

The second prong in Epstein's attack on disparate impact is his assertion that it is massively costly to firms. This assertion, like so many others, is never supported by anything more than anecdotal evidence.

Take the issue of employment testing as an example. Employment tests with differential pass rates for black and white applicants have often been the subject of disparate impact litigation, ${ }^{67}$ and Epstein claims that "it is apparent that [Griggs] has had a profound impact on the way in which testing is done at all levels of the employment process" (at 236). It is true that Griggs and subsequent decisions-in concert with the EEOC's Guidelines on Employee Selection Procedures-have increased pressure on employers to document the "job relatedness" of their tests through careful validation studies. It is possible that the use of testing has decreased since Griggs, with firms substituting (possibly) less effective methods of screening workers. But Epstein presents no evidence that any part of this compound statement is true, and indeed no such evidence exists, as far as I know.

Epstein cites one estimate that a more systematic use of testing would raise productivity by some $\$ 80$ billion (in 1983 dollars). This figure, however, is an obvious overstatement of the value of testing, because it takes the possible gains from testing (selection of better workers) accruing to a single firm and then scales them up to cover the entire economy. Assuming all workers work at some firm, one employer's gain from rejecting a low-productivity worker will be largely offset by another employer's loss at having to take that same worker. ${ }^{68}$ In sum, there may be a case to be made that the civil rights regime has been too hard on testing, but we are a long way from having the evidence for such a claim.

Despite the exaggerations and rhetorical overkill to which he is prone, Epstein's attack on disparate impact does in my view cast some serious doubts about the wisdom of prohibiting this kind of discrimination.

66. Any labor economist would recognize this as a problem of "endogeneity bias." Cain offers a measured discussion of this problem, in nontechnical language, in "The Uses and Limits of Statistical Analysis in Mcasuring Discrimination," in Emily Hoffman, ed., Essays on the Economics of Discrimination (Kalamazoo, Mich.: W. E. Upjohn Institute, 1991); he concludes that historical context is critical, and statistical analysis alone cannot completely resolve the question of how much discrimination there is.

67. E.g., Albemarle Paper Co. v. Moody, 422 U.S. 405 (1975); Evans v. City of Evanston, 881 F.2d 382 (7th Cir. 1989).

68. This point was first made by a National Research Council report on testing (John Hartigan \& Alexandra Wigdor, eds., Faimess in Employment Testing (Washington: National Academy Press, 1989)). There may be some gains to be had from matching firms and workers, but these are found to be quite small in the only empirical study of which I am aware. See James Heckman \& Guilherme Sedlacek, "Self-Selection and the Distribution of Hourly Wage Rates," 8 J. Lab. Econ. S329 (1990). 
Although we certainly do not know enough to be sure it is a terrible idea, we do know enough to think that there are some real problems associated with it.

As an example of Epstein's logic at its most persuasive, consider his analysis of the Teal decision. ${ }^{69}$ In that case, the plaintiff was one of 48 black and 259 white candidates to apply for a promotion in the Connecticut welfare department. Ms. Teal failed the initial written examination, as did $45.8 \%$ of the other black applicants; only about $20 \%$ of the white applicants failed, yielding a pass rate for blacks that was $68 \%$ of the white pass rate. In the second stage of the process, however, the state promoted 11 of the 26 blacks who passed (42\%) and 35 of the 206 whites (17\%).

The question addressed by the Supreme Court was whether a nondiscriminatory "bottom line" (overall result) was enough to insulate an employer from disparate impact liability under Title VII, even though a preliminary stage in the selection process did have a disparate impact against a minority group. It was answered in the negative. As Epstein points out, however, the consequences of this decision are unfortunate. The decision made Ms. Teal eligible to compete for promotion with all of those others (black and white) who scored better than she did on the initial test. If the overall black/white hiring ratio were maintained (as seems likely, given Connecticut's emphasis on the "bottom line," amounting to a virtual racial quota), then the chief result of the decision was to substitute a lessqualified black applicant (Teal) for another black applicant who scored higher than she did on the test. As Epstein points out, this does not seem as if it can be sensible public policy, no matter how strongly one believes in civil rights. ${ }^{70}$

\section{CONCLUSION}

In Forbidden Grounds, Richard Epstein has marshaled his considerable intelligence, learning, and rhetorical skill to make the case that employment discrimination laws are a bad idea and should be gotten rid of. I write this as President Clinton has announced his choice for the new Deputy Attorney General to head the Civil Rights Division of the Justice Department, and I would not have been surprised to see Epstein's book cited at Deval Patrick's confirmation hearings. As far as I know, no one held up a copy in front of the TV cameras, the way Senator Joseph Biden did with Epstein's previous book during the hearings to confirm Clarence Thomas's

69. Connecticut v. Teal, 457 U.S. 440 (1981).

70. If one believes that the test had no predictive power at all, then the fact that Ms. Teal scored lower than some other black applicant whose place she took is irrelevant, and the decision look more reasonable. 
appointment to the Supreme Court. ${ }^{71}$ In any event, the book is bound to be influential because it makes a very confident argument that will be appealing to those who believe that the antidiscrimination principle has gone too far.

But how much influence should the book have? Or put more bluntly, is Epstein right? I believe that although he has scored some legitimate blows against the antidiscrimination regime that governs employment decisions, he is more often off the mark than on target.

What I find particularly disturbing are not his arguments themselves, however, but the excessive, almost zealous, confidence with which they are made. Epstein's world, like that of any true believer, doesn't allow for messy empirical reality, for questions of "how much" or "how severe" or "how often." There is of course an important place for debates between clashing worldviews, and Epstein joins that debate effectively. But although not all questions are empirical, some are, and economists, in particular, need to make it clear that our limited knowledge and theories do not allow for the kinds of bold conclusions that Epstein draws on almost every page of Forbidden Grounds.

71. Epstein's previous book was Takings, an attack on governmental regulation of land use. 
